\title{
Co-thermal degradation characteristics of rice straw and sewage sludge
}

\author{
Thi Ngoc Lan Thao Ngo and Kung-Yuh Chiang
}

\begin{abstract}
Co-thermal treatment of binary biomass mixture is an alternative to enhance the refractory decomposition of biomass thermal degradation efficiency resulted in the synergistic reaction. Rice straw (RS) containing a large amount of fixed carbon ( $F C$ ) is quite difficult to thermally decompose at a lower temperature. Considering the RS and sewage sludge (SS), co-thermal treatment for enhancing energy conversion efficiency was feasible. This study investigates the kinetic behaviors and gas evolution of RS, SS, and their blends under co-thermal decomposition processes using Thermogravimetric analysis combined with Fourier-Transform Infrared Spectroscopy (FTIR). The experimental results indicate that SS could enhance the volatile matter decomposition in RS co-thermal process at lower temperatures. Activation energy decreases from 53 to $49 \mathrm{~kJ} \mathrm{~mol}^{-1}$ with an increase in SS addition from 50 to $80 \%$ under pyrolysis conditions. The major volatile components were aliphatic chains with double bonds, as well as carbonyl, hydroxyl, and C-H groups in organic compounds by FTIR identification. The tested materials characteristics in terms of volatile matter (VM)-to-FC ratio significantly affected the thermal degradation performance. Activation energy was decreased with increasing the VM/FC ratio. It implied that co-thermal reaction could be accelerated. In summary, the results could provide the important information for co-thermal treatment of SS and RS in application for commercial-scale plant design.
\end{abstract}

Keywords: Rice straw, Sewage sludge, Kinetic analysis, TGA-FTIR, Pyrolysis, Gasification

\section{Introduction}

Approximately $170 \mathrm{kt}$ (based on $80 \%$ moisture content) of sewage sludge (SS) derived from municipal wastewater treatment plants (WWTPs) are generated in Taiwan annually [1]. The amount of SS is expected to dramatically increase due to the rapid increase in sewer system establishment and stringent requirements for water resources protection. Sanitary landfills are currently a major solution for SS final disposal. Rice production is one of the most important agricultural activities in Taiwan. The average rice straw (RS) generation is nearly 1.5 Mt annually [2]. The common traditional habits of farmers include open firing RS treatment. However, this option will not be sustainable at current or projected levels due to increasing competition for landfill space,

\footnotetext{
* Correspondence: kychiang@ncu.edu.tw

Graduate Institute of Environmental Engineering, National Central University, Tao-YuanCity, 32001, Taiwan
}

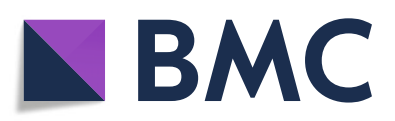

(c) The Author(s). 2021 Open Access This article is licensed under a Creative Commons Attribution 4.0 International License, which permits use, sharing, adaptation, distribution and reproduction in any medium or format, as long as you give

appropriate credit to the original author(s) and the source, provide a link to the Creative Commons licence, and indicate if changes were made. The images or other third party material in this article are included in the article's Creative Commons licence, unless indicated otherwise in a credit line to the material. If material is not included in the article's Creative Commons licence and your intended use is not permitted by statutory regulation or exceeds the permitted use, you will need to obtain permission directly from the copyright holder. To view a copy of this licence, visit http://creativecommons.org/licenses/by/4.0/.

higher costs, more stringent environmental standards, and the implementation of policies to promote recycling. Energy recovery from RS and/or SS has become an attractive solution using thermal chemical conversion processes including combustion, torrefaction, pyrolysis, and gasification. The valuable products, such as heat, syngas, bio-char, and/or bio-oil can convert from sludge, waste, and biomass via above thermal technologies. It does not only generate bioenergy, but also effectively reduce the impact of traditional sanitary landfilling to the environment. Especially, in comparison with other thermal cracking technologies, gasification could turn waste into gaseous product with higher calorific value, higher carbon conversion and has the advantage to be widely applied for chemical products development [3-10]. Even though the SS has been treated by traditional dewatering methods, one of the issues of public concern for energy conversion is SS containing relatively high moisture content (approximately $60-80 \%$ ) resulting in low energy 
yield. The use of SS and other types of organic wastes could be an alternatives technology for solving the obstacles and improving the energy yield. To cope with the increasingly stringent regulations, constantly rising treatment cost and final disposal cost of SS and RS, the Taiwan government planned to establish strategies and develop innovative technologies for treating the above wastes and achieving the circular economy target. Among the thermal conversion technologies, gasification is an innovative technology because it has several potential advantages associated with high carbon conversion, high calorific value synthesis gas, and flexible biomass utilization and/or agricultural waste-to-energy [3]. On the other hand, SS and biomass (pine sawdust) cogasification was also investigated [4]. The literature results indicated that co-gasification could improve volatile matter thermal behavior and enhance energy conversion efficiency.

Thermogravimetric analysis (TGA) has become a common analysis technique to investigate thermal behavior and kinetics. This involves the weight loss characterization of tested materials as a function of the reaction temperature controlled in simulated thermal reaction atmospheres. Typical TGA advantages are accurate real-time sample mass measurements, high reproducibility, and well-defined temperature and gasphase conditions [11, 12]. TGA has been applied to the study of SS, RS, woody biomass, plastics, and other organic waste thermal characteristics using simulated pyrolysis conditions $[4,13,14]$. TGA can be coupled with spectrometers, such as Fourier transform infrared spectroscopy (FTIR), to analyze the temporal resolution of specific gas-phase fragments. This contributes to the analysis and understanding of thermal degradation mechanisms for waste and/or biomass treatment [15-18].

Moreover, little information has been collected on the relationships between waste and/or biomass characteristics, reaction kinetics, and gaseous speciation during the thermal degradation process. Moreover, biomass properties play important roles in thermal degradation process. Some parameters such as VM, fixed carbon (FC), moisture, or elemental contents $(\mathrm{C}, \mathrm{H}, \mathrm{N}, \mathrm{S})$ are key factors that affect the energy conversion process. The VM and FC contents in biomass are practical parameters for evaluating the volatility and ignitability [19]. Practically, the different characteristics of biomass fuels from coal to plastic include their higher VM and lower carbon content. Pyrolysis and gasification system modifications need to consider these characteristics along with other factors. Therefore, the objectives of this research were: (1) to determine the kinetic triplets (activation energy, Arrhenius const. and reaction order) in co-thermal degradation of RS, SS, and their blends; (2) to understand the characteristics of gas evolution and possible speciation during the co-thermal degardation process; and (3) to investigate the relationship between the tested materials characteristics and kinetic triplets during the co-thermal degradation process.

\section{Materials and methods \\ Materials}

The feedstocks used for the co-thermal process in this research were SS and RS. SS was obtained from Dihua urban WWTP, which was established in July 1980 with a capacity of $500,000 \mathrm{~m}^{3} \mathrm{~d}^{-1}$ in Taipei City, Taiwan. SS was treated using gravity thickening, anaerobic digestion, and dewatering. To reduce the sludge volume and save transportation cost, SS is dewatered by drying prior to the final disposal. RS was collected from Chung-Li District, Tao-Yuan city located in the northern part of Taiwan. RS and SS were first dried, shredded, and sieved to extract a particle size between 150 and $210 \mu \mathrm{m}$ by laboratory oven, crusher, and sieve, which were manufactured by Melojia Enterprise Co. Taiwan. In order to precisely analyze the thermal reaction, RS was pelletized using a mini-pellet press due to its light and bulky properties. Proximate analysis indicated the percentage by weight of moisture, ash content, VM, and FC. The tested samples were determined in triplicate using regulation testing procedures specified by the Taiwan Environmental Protection Administration and the Chinese National Standards, which are similar to the American Standard for Testing Materials. The ultimate analysis of the combustibles in the SS and RS was also analyzed in triplicate using an elemental analyzer (Elemental Analyzer Vario MICRO cube, Thermo Fisher Scientific, Germany). The energy contents in SS and RS were determined using a bomb calorimeter (Parr 1341 calorimeter, Parr Instrument, USA).

\section{Experimental conditions}

TGA is a common technique used to understand thermal behavior and investigate the reaction kinetics in RS and SS co-pyrolysis and/or gasification. The TA analyzer used in this study is a commercially available laboratory instrument (TGA-STA 7300, Thermal Analysis System, Thermo Fisher Scientific, Hitachi, Japan). The dried SS was prepared by drying and mixing with 20,40 , and 50 $w t \%$ of RS, respectively. RS and their blends were evaluated using TGA and TGA-FTIR (Frontier MIR/FIR Spectrometer, Thermo Fisher Scientific, USA). To determine the thermal reaction conditions, raw materials were placed in a ceramic crucible $5 \mathrm{~mm}$ in inner diameter and $5 \mathrm{~mm}$ in height. A precision balance constantly weighed the crucible carrying the samples with a resolution of $0.1 \mu \mathrm{g}$. The TGA experiments were performed from 40 to $1000^{\circ} \mathrm{C}$ and operated at heating rates of 5 , $10,20^{\circ} \mathrm{C} \mathrm{min}{ }^{-1}$ in different pyrolysis and/or gasification 
atmospheres. In the pyrolysis experiments, about $3 \mathrm{mg}$ of the tested samples were pyrolyzed under $100 \mathrm{~mL}$ $\min ^{-1}$ with $100 \% \mathrm{~N}_{2}$ as the carrier gas. A gasification experiment was established to utilize the partial combustion of RS and SS by carefully controlling the amount of air as an oxidizer. The amount of oxidizer can be calculated corresponding to the equivalence ratio at 0.35 and theoretical air demand of RS and SS at 4.18 and 4.42 $\mathrm{Nm}^{3} \mathrm{~kg}^{-1}$, respectively, the total time needed for the entire process was calculated. As the result, the air input flow rates are $0.3,0.5$, and $1.0 \mathrm{~mL} \mathrm{~min}^{-1}$ corresponding to heating rate at 5,10 , and $20^{\circ} \mathrm{C} \mathrm{min}^{-1}$, respectively. To further simulate the gasification, atmosphere air and nitrogen was well-mixed as the carrier gas are controlled between 0.3 and $1.0 \mathrm{vol} \%$ air mixing ratio under total a flow rate of $100 \mathrm{~mL} \mathrm{~min}^{-1}$. A change in the heating rates brings a corresponding change in air $/ \mathrm{N}_{2}$ ratios of 0.3 / 99.7, 0.5/99.5, and 1.0/99.0, respectively. Figure 1 illustrates the schematic diagram of an experimental set-up for TGA-FTIR.

\section{Kinetic analysis}

The thermal decomposition reaction kinetics of carbonaceous materials is complicated. The kinetic parameters were determined, including activation energy, reaction order, and pre-exponential factor. The activation energy was determined using the integral method that can be simply expressed as the Arrhenius equation:

$$
\frac{\mathrm{dX}}{\mathrm{dT}}=-\mathrm{Ae}^{-\left(\frac{\mathrm{E}}{\mathrm{RT}}\right)} \mathrm{X}^{\mathrm{n}}
$$

where

A: pre-exponential or frequency factor $\left(\mathrm{min}^{-1}\right)$;

$\mathrm{E}$ : decomposition reaction activation energy $\left(\mathrm{kJ} \mathrm{mol}^{-1}\right)$;

$\mathrm{X}^{\mathrm{n}}$ for the dependence of extent of conversion (X) in relation to reaction model with order of reaction (n);
$\mathrm{X}=\left(m_{0}-m_{t}\right) /\left(m_{0}-m_{f}\right)$, where $\mathrm{m}_{0}$ and $\mathrm{m}_{\mathrm{f}}$ for the initial mass and the final mass, respectively; and $m_{t}$ for the mass of the sample at temperature $T$.

$\mathrm{R}$ : universal gas constant $\left(\mathrm{kJ} \mathrm{mol}^{-1} \mathrm{~K}^{-1}\right)$;

t: time (min); $\mathrm{T}$ : absolute temperature (K).

The multiple linearized regression form of the Arrhenius equation was used to determine $\mathrm{A}, \mathrm{E}$, and $\mathrm{n}$ by applying a least-squares (multiple linear regression) technique. The ideas for calculating reaction order were introduced by previous published literature [20]. Multiple regression analysis can be regarded as an extension of straight-line regression to the situation in which more than one independent variable must be considered. The implied form of the linearized rate equation is

$$
\mathrm{y}=\mathrm{B}+\mathrm{Cx}+\mathrm{Dz}
$$

The parameters $\mathrm{y}, \mathrm{x}, \mathrm{z} \mathrm{B}, \mathrm{C}$, and D in Eq. (2) are defined as follows.

$$
\begin{aligned}
& y=\ln \left\{\left[\frac{-1}{\left(w_{o}-w_{f}\right)}\right]\left(\frac{d w}{d t}\right)\right\} \\
& x=\frac{1}{R T} \\
& z=\ln \left\{\frac{\left(w^{-}-w_{f}\right)}{w_{o}-w_{f}}\right\}
\end{aligned}
$$

where $\mathrm{w}$ : weight of sample at time $\mathrm{t}(\mathrm{min})$; $\mathrm{w}_{\mathrm{f}}$ : weight of residue at the end of the reaction $(\mathrm{g})$; and $\mathrm{w}_{\mathrm{o}}$ : initial weight of the sample. The coefficients B, C, and D in Eq. (2), which correspond to the logarithm of the preexponential factor $\ln \mathrm{A}$; the activation energy $\mathrm{E}$; and the reaction order $\mathrm{n}$, respectively, were determined for each type of RS, SS and their mixture through the multiple linear regression analysis methods using thermogravimetric data by Statistica software (Data analysissoftware system, version 10, StatSoft, Europe).

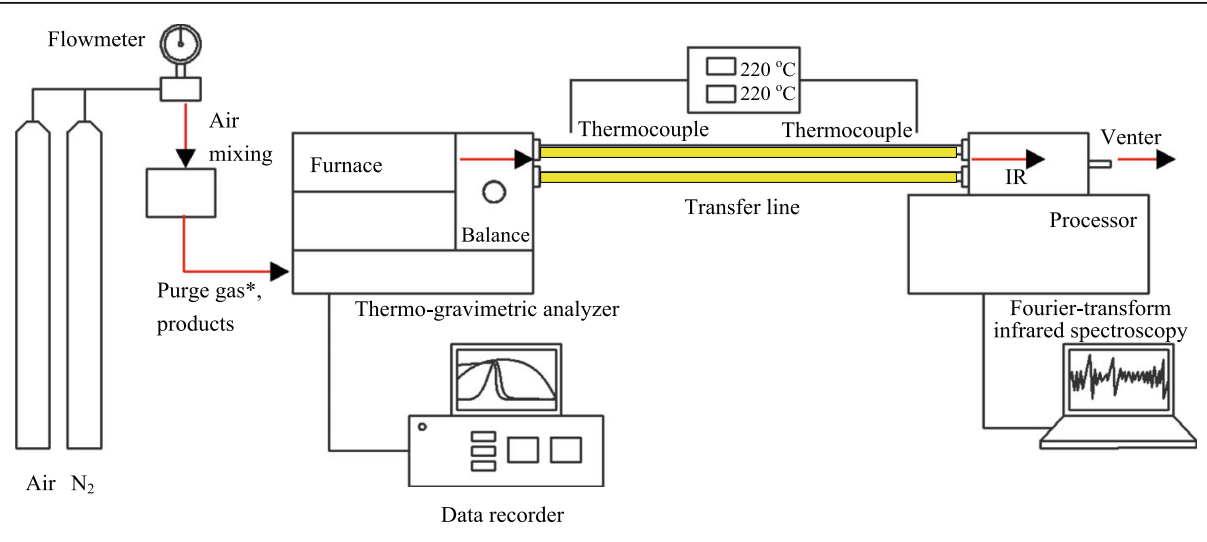

Note the purge gas* used were nitrogen and air for TGA and TGA-FTIR, respectively.

Fig. 1 Schematic diagram of TGA-FTIR experiment 


\section{Results and discussion}

\section{Analysis results of thermal kinetic}

\section{Comparison between the pyrolysis and gasification of RS}

The physical-chemical characteristics of RS and SS are shown in Table 1. Elemental analysis shows that tested samples have high carbon content at nearly $40 \%$. The higher heating value of SS $\left(17.6 \mathrm{MJ} \mathrm{kg}^{-1}\right)$ was higher than that of RS (15.9 $\left.\mathrm{MJ} \mathrm{kg}^{-1}\right)$. The higher heating value of these materials has proven that SS and RS have potential as bio-fuel for themal processes. Nevertheless, $\mathrm{VM}$, the key factor in thermal conversion process is on average at 59.4 and $64.2 \%$ from SS and RS, respectively.

Figure 2 shows TGA (in wt\%) and derived thermogravimetric DTG (in wt\% $\mathrm{min}^{-1}$ ) curves obtained during the decomposition of RS in pyrolysis and gasification at heating rates of $10{ }^{\circ} \mathrm{C} \mathrm{min}{ }^{-1}$ from 40 to $1000{ }^{\circ} \mathrm{C}$. From the DTG curves, it could be illustrated that only one peak is observed in the DTA graph corresponding to the number of degradation stages. Besides, the temperature of the peak in the DTA corresponds to the temperature at which max degradation occurs. As observed in Fig. 2, the pyrolysis process can be divided into three main stages. The first stage $\left(40-178^{\circ} \mathrm{C}\right)$ corresponds to the moisture lost during drying, about $1.7 \mathrm{wt} \%$ of RS. The second step $\left(179-500{ }^{\circ} \mathrm{C}\right)$ relates to organic matter decomposition, and about $57.8 \mathrm{wt} \%$ of the biomass was lost during this stage. The final stage $\left(>500{ }^{\circ} \mathrm{C}\right)$ is inorganic matter degradation (residual). The sample weight loss during RS pyrolysis was $71.5 \mathrm{wt} \%$. The weight decreased rapidly, attributed mainly to cellulose, hemicellulose, and partial lignin devolatilization [21]. The lignin decomposition continued to give a gradual weight loss beyond $450{ }^{\circ} \mathrm{C}$. Hemicellulose and cellulose pyrolysis occurred rapidly in the range of $250-340$ and $340-400{ }^{\circ} \mathrm{C}$,

Table 1 Characteristic of tested sewage sludge and rice straw

\begin{tabular}{lll}
\hline & Sewage sludge & Rice straw \\
\hline Proximate analysis (wt\%) & & \\
Moisture & $6.7 \pm 0.9$ & $10.5 \pm 1.0$ \\
Ash & $23.0 \pm 0.1$ & $9.6 \pm 0.2$ \\
VM & $59.4 \pm 0.2$ & $64.2 \pm 0.5$ \\
FC & 10.9 & 15.8 \\
Ultimate analysis (wt\%, dry basis) & \\
C & $39.7 \pm 0.9$ & $39.9 \pm 0.6$ \\
H & $5.9 \pm 0.2$ & $6.2 \pm 0.2$ \\
N & $6.5 \pm 0.2$ & $0.9 \pm 0.1$ \\
S & $1.1 \pm 0.1$ & $0.2 \pm 0.1$ \\
O & 17.0 & 32.8 \\
Energy content $\left(\mathrm{MJ} \mathrm{kg}^{-1}\right)$ & & \\
HHV & $17.6 \pm 0.1$ & $15.9 \pm 0.3$ \\
LHV & 14.6 & 12.1 \\
\hline
\end{tabular}

respectively, contributing to a sharp drop in the TG profile. The obtained results are in good agreement with those by Lin et al. [22].

In a partial oxidative atmosphere (gasification process), RS thermal degradation can be classified into three steps, (i) moisture evaporation, (ii) cellulose, and hemicellulose pyrolytic decomposition and (iii) lignin and char oxidative pyrolytic decomposition. The first step was from room temperature to $175^{\circ} \mathrm{C}$, with about $3.4 \mathrm{wt} \% \mathrm{RS}$ loss. The second step is the fast decomposition stage, from 176 to $530{ }^{\circ} \mathrm{C}$. About $55.9 \%$ of the weight is lost during this stage. During the entire gasification process, weight loss is about $70.5 \%$. The RS weight loss performance was similar under both pyrolysis and gasification conditions at low temperatures, showing that the presence of air atmosphere did not contribute to the increasing decomposition rate.

\section{Effect of added SS on thermal performances}

As seen in Fig. 2, a comparison between the pyrolysis/ gasification behavior of SS and RS blends can also be made. According to the results, the weight loss profiles for RS, SS, and additives obtained from pyrolysis slightly differ from those of gasification. Thermal degradation of both RS, SS and their additives during pyrolysis under an inert atmosphere can be classified into three main stages including (i) moisture evaporation, (ii) organics devolatilization, and (iii) inorganic devolatilization. The beginning and ending temperatures of the decomposition process are important characteristic parameters for feedstocks. In the case of pyrolysis, the beginning SS and RS temperatures were 153 and $178^{\circ} \mathrm{C}$, and the corresponding ending temperatures were 517 and $500{ }^{\circ} \mathrm{C}$, respectively. For SS and their blends, the major decomposition temperature at a lower temperature range varies ranged between 147 and 173 and $515-535^{\circ} \mathrm{C}$. The final temperature for weight loss of SS and their blends at the end is approximately $535^{\circ} \mathrm{C}$ due to the fact that FC could not decompose at this temperature. RS and SS have narrow decomposition temperature ranges for adding RS samples resulting in $\mathrm{T}_{\mathrm{i}}$ decreasing by $5-31^{\circ} \mathrm{C}$. This indicates that adding SS to RS results in shifting to lower initial decomposition temperature compared to that of RS. Comparing with the pyrolysis process, DTG gasification performance curves also show one prominent reaction zone existing in the heating rate range studied and the weight loss of SS, RS and their blends have the same trends (Fig. 2b). The weight loss curve results for the tested samples are recognized to have similar trends, meaning that these materials have potentially promising applications in co-pyrolysis/gasification. This proves that biomass and their blends have the same pyrolysis and gasification thermal decomposition behavior and the thermal degradation of all materials occurred in the three stages. 


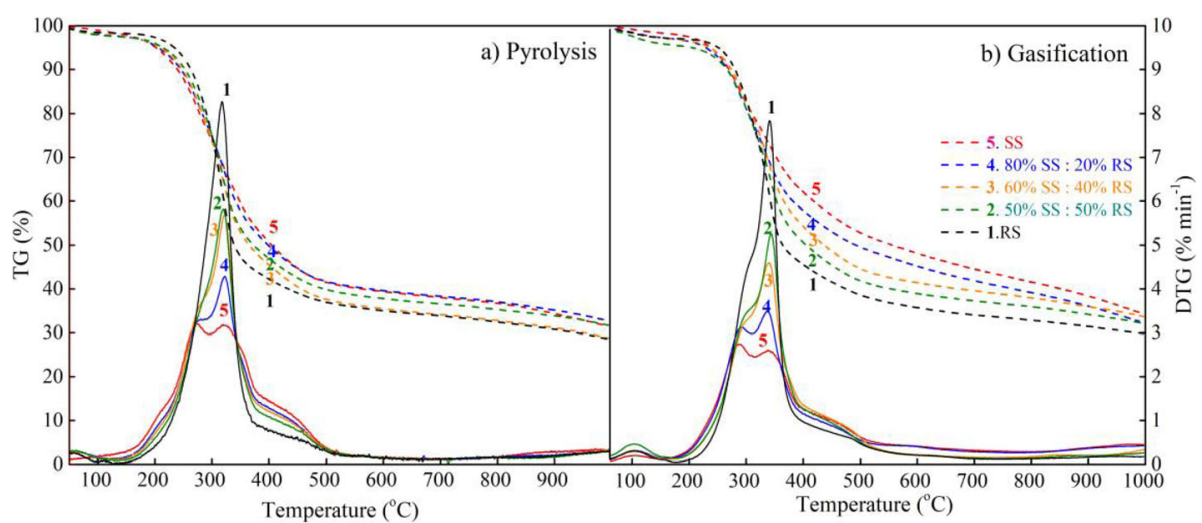

Fig. 2 A comparison between TG/DTG curves detected from rice straw, sewage sludge and their additives pyrolysis and air gasification at $10^{\circ} \mathrm{C}$ $\mathrm{min}^{-1}$ heating rate

\section{Thermal decomposition kinetics of different types of biomass}

Table 2 summarizes some characteristic parameters obtained from pyrolysis/gasification thermogravimetric data. The calculating reaction order idea was introduced in numerous studies [4, 35]. The biomass reaction order was found at around 0.69-3.57 (as indicated in Table 2) [23-34, 36, 37]. These include the temperatures for the initial weight loss $\left(T_{i}\right.$ at the end of the reaction $\left(T_{f}\right)$, and the corresponding peak temperatures $\left(\mathrm{T}_{\mathrm{P}}\right)$ of thermal decomposition behavior with different types of biomass such as RS, sugarcane baggage, pinewood, SS, via Arrhenius law in the literature [23-34]. Biomass kinetic analysis plays an important role in determining the reaction kinetics necessary for mathematical modeling and reactor operational parameter optimization. TGA of raw materials was therefore considered during the pyrolysis/ gasification conditions.

The physical characteristic of the wastes influences the thermal process related to the temperature peak $\left(T_{p}\right)$. Under thermal conditions, when these materials are exposed to high temperatures, their structure, and atomic configuration are changed, which causes some exothermic or endothermic peaks to appear in the thermal diagram [38]. When the DTG curves have a peak, it implies that at this temperature, the molecular relaxation becomes greater and promotes the process to a faster reaction rate. Table 2 illustrates the peak temperature for the decomposition process, which occurs mostly in the $270-350^{\circ} \mathrm{C}$ range. Higher peak temperatures $358-$ $491^{\circ} \mathrm{C}$ were found, particularly in coal and polypropylene. VM is highly thermal sensitive. High VM content indicates that a large amount of weight will be lost under high temperatures in the thermal process. Maintaining the pyrolysis/gasification temperature below $\mathrm{T}_{\text {final }}$ (maximum temperature) to avoid significant mass and energy loss must be carefully considered [39]. Furthermore, some wastes are under incomplete decomposition conditions in the temperature range near $600{ }^{\circ} \mathrm{C}$. This may suggest that the pyrolysis temperature must be controlled at lower degrees than $600{ }^{\circ} \mathrm{C}$ in order to ensure that the majority of the material reacts and decomposes.

In general, material that has low activation energy requires more input energy demand. Therefore, the tested sludge has higher FC content that it requires more energy for the thermal decomposition process. To further understand the enhanced syngas yield tendency in gasification-oxidation reaction $\left(\mathrm{C}+1 / 2 \quad \mathrm{O}_{2} \rightarrow \mathrm{CO}\right)$, the carbon-to-FC ratio was used as an index for the gasification reaction. The experimental results indicated that the activation energy of the tested sludge samples ranged from 50 to $100 \mathrm{~kJ} \mathrm{~mol}^{-1}$ with $\mathrm{C} / \mathrm{FC}$ ratio ranged between 2 and 4 . It implied that the tested sludge could easily produce more $\mathrm{CO}$ which improves lower heating value of the producer gas due to partial carbon oxidation reaction. The kinetics of co-pyrolysis/gasification were thoroughly investigated by others [40-42]. The experimental results indicated that biomass could enhance the degradation of plastics corresponding to an increase in light liquid products [40]. Co-pyrolysis of biomass and plastic could promote high quality chars with higher calorific values as compared bio-chars only generated in biomass pyrolysis [41]. The iso-conversion method was developed by previous research that could calculate the kinetic parameters in co-pyrolysis of microalgae biomass and low-rank coal [42]. Therefore, TGA results could contribute to enhance the knowledge of tested materials containing high $\mathrm{C} / \mathrm{FC}$ ratio thermal degradation characterization and to establish the optimum operation conditions for syngas production.

Table 3 shows some kinetic parameters (activation energy and pre-exponential factor) and temperature range of thermal decomposition behavior of RS, SS, and blends obtained from pyrolysis and gasification simulations. 
Table 2 Comparison of the kinetic analysis in this study and those in the literature

\begin{tabular}{|c|c|c|c|c|c|c|c|c|c|c|}
\hline Feedstocks & Carrier gas & $\begin{array}{l}\text { Flow rate } \\
\left(\mathrm{mL} \min ^{-1}\right)\end{array}$ & $\mathrm{Ti}$ & $T_{p 1}$ & $T_{f}$ & $\mathrm{E}\left(\mathrm{kJ} \mathrm{mol} \mathrm{l}^{-1}\right)$ & $A\left(\min ^{-1}\right)$ & $\mathbf{n}$ & $\mathrm{R}^{2}$ & Ref. \\
\hline \multirow[t]{2}{*}{ RS } & $\mathrm{N}_{2}$ & 100 & 178 & 319 & 500 & 75.4 & $18.6 \times 10^{6}$ & 1.43 & 0.82 & \multirow[t]{2}{*}{ This study } \\
\hline & Air & 100 & 175 & 323 & 530 & 89.6 & $0.59 \times 10^{8}$ & 2.12 & 0.71 & \\
\hline SS & $\begin{array}{l}\mathrm{N}_{2} \\
\text { Air }\end{array}$ & $\begin{array}{l}100 \\
100\end{array}$ & $\begin{array}{l}153 \\
148\end{array}$ & $\begin{array}{l}272,321 \\
273,325\end{array}$ & $\begin{array}{l}517 \\
550\end{array}$ & $\begin{array}{l}49.1 \\
60.1\end{array}$ & $\begin{array}{l}1.37 \times 10^{5} \\
1.97 \times 10^{5}\end{array}$ & $\begin{array}{l}2.41 \\
3.57\end{array}$ & $\begin{array}{l}0.90 \\
0.84\end{array}$ & This study \\
\hline $20 \% \mathrm{RS}+80 \% \mathrm{SS}$ & $\begin{array}{l}\mathrm{N}_{2} \\
\text { Air }\end{array}$ & $\begin{array}{l}100 \\
100\end{array}$ & $\begin{array}{l}173 \\
154\end{array}$ & $\begin{array}{l}324 \\
279,324\end{array}$ & $\begin{array}{l}535 \\
659\end{array}$ & $\begin{array}{l}48.6 \\
63.7\end{array}$ & $\begin{array}{l}0.71 \times 10^{5} \\
5.40 \times 10^{5}\end{array}$ & $\begin{array}{l}1.52 \\
3.3\end{array}$ & $\begin{array}{l}0.86 \\
0.81\end{array}$ & This study \\
\hline \multirow[t]{2}{*}{$40 \% \mathrm{RS}+60 \% \mathrm{SS}$} & $\mathrm{N}_{2}$ & 100 & 154 & 321 & 515 & 50.6 & $0.84 \times 10^{5}$ & 0.9 & 0.84 & \multirow[t]{2}{*}{ This study } \\
\hline & Air & 100 & 160 & 323 & 551 & 64.3 & $14.4 \times 10^{5}$ & 2.45 & 0.78 & \\
\hline \multirow[t]{2}{*}{$50 \% \mathrm{RS}+50 \% \mathrm{SS}$} & $\mathrm{N}_{2}$ & 100 & 147 & 320 & 516 & 53.1 & $1.44 \times 10^{5}$ & 0.69 & 0.83 & \multirow[t]{2}{*}{ This study } \\
\hline & Air & 100 & 166 & 325 & 534 & 68.7 & $19.1 \times 10^{5}$ & 2.26 & 0.80 & \\
\hline RS & \multirow[t]{2}{*}{$\mathrm{N}_{2}$} & 100 & 266 & 320 & 353 & 59.9 & $2.4 \times 10^{4}$ & 1.0 & 0.995 & \multirow[t]{2}{*}{ [23] } \\
\hline SS & & 100 & 248 & 310 & 385 & 19.7 & 13.91 & 1.0 & 0.998 & \\
\hline SS & $\mathrm{N}_{2}$ & 50 & 150 & 299 & 550 & 31.9 & 27.35 & 1.1 & 0.982 & [24] \\
\hline SS & $\mathrm{H}_{2} \mathrm{O}-\mathrm{Ar}$ & 150 & - & & - & 65.7 & $3.9 \times 10^{3}$ & 1.0 & 0.998 & {$[25]$} \\
\hline Industrial sludge & & 150 & 227 & - & 527 & 68.1 & $1.07 \times 10^{4}$ & 1.0 & 0.991 & \\
\hline Fluff & & 150 & 227 & - & 527 & 83.0 & $1.27 \times 10^{5}$ & 1.0 & 0.951 & \\
\hline Scrap tire powder & & 150 & 227 & - & 527 & 132 & $4.1 \times 10^{8}$ & 1.0 & 0.994 & \\
\hline Rice husk & $\mathrm{N}_{2}$ & 100 & 172 & 348 & 576 & 87.4 & $1.32 \times 10^{7}$ & - & 0.984 & [26] \\
\hline \multirow[t]{2}{*}{ Rice husk } & Air (1st zone) & \multirow[t]{2}{*}{-} & 191 & 321 & - & 53.4 & $3.77 \times 10^{6}$ & 1.41 & - & \multirow[t]{2}{*}{ [27] } \\
\hline & Air (2nd zone) & & 321 & - & 510 & 20.8 & $1.41 \times 10^{3}$ & 0.47 & & \\
\hline \multirow[t]{2}{*}{ Sugarcane bagasse } & $\mathrm{N}_{2}$ (1st zone) & 20 & 140 & 325 & - & 53.5 & 0.28 & 0.4 & 0.995 & \multirow[t]{4}{*}[28]{} \\
\hline & $\mathrm{N}_{2}$ (2nd zone) & & 325 & - & 493 & 43.0 & 0.15 & 0.3 & 0.971 & \\
\hline \multirow[t]{2}{*}{ Cotton stalks } & $\mathrm{N}_{2}$ (1st zone) & 20 & 150 & 287 & - & 102 & 1.22 & 1.0 & 0.997 & \\
\hline & $\mathrm{N}_{2}$ (2nd zone) & & 287 & - & 471 & 98.5 & 0.45 & 0.7 & 0.966 & \\
\hline Chlorella vulgaris & Air & 25 & 165 & - & 367 & 41.0 & 3.9981 & - & - & [29] \\
\hline Pine wood & $\mathrm{N}_{2}$ & 45 & 245 & - & 405 & 68.7 & $1.75 \times 10^{2}$ & - & - & \multirow[t]{2}{*}{ [30] } \\
\hline Activated carbon & $\mathrm{N}_{2}$ & 45 & 80 & - & 800 & 5.30 & $6.43 \times 10^{-5}$ & - & - & \\
\hline Coal Char & $\mathrm{N}_{2}$ & 600 & 506.5 & & 653.3 & 130-153 & $7.12 \times 10^{3}$ & 1.0 & $>0.96$ & [31] \\
\hline Coal Char & $\mathrm{CO}_{2}$ & $200-500$ & 760 & - & 820 & 285 & $3.9 \times 10^{11}$ & - & - & [32] \\
\hline \multirow[t]{2}{*}{ Coal } & Air & 50 & - & - & - & 52.7 & $3.3 \times 10^{9}$ & - & - & \multirow[t]{2}{*}{ [33] } \\
\hline & $\mathrm{O}_{2}$ & 50 & - & - & - & 93.1 & $1.3 \times 10^{10}$ & - & - & \\
\hline \multirow[t]{3}{*}{ Coal } & $\mathrm{N}_{2}$ (1st zone) & 30 & 174 & 358 & - & 36.9 & 378 & 1.0 & 0.986 & \multirow[t]{6}{*}{ [34] } \\
\hline & $\mathrm{N}_{2}$ (2nd zone) & & 358 & 491 & - & 129 & $5.5 \times 10^{8}$ & & 0.995 & \\
\hline & $\mathrm{N}_{2}$ (3rd zone) & & 491 & - & 667 & 115 & $1.8 \times 10^{6}$ & & 0.976 & \\
\hline HDPE & $\mathrm{N}_{2}$ & 30 & 439 & - & 523 & 457 & $3.5 \times 10^{30}$ & 1.0 & 0.998 & \\
\hline LDPE & $\mathrm{N}_{2}$ & 30 & 426 & - & 526 & 300 & $2.2 \times 10^{20}$ & 1.0 & 0.998 & \\
\hline Plastic (PP) & $\mathrm{N}_{2}$ & 30 & 399 & 491 & 507 & 320 & $5.9 \times 10^{21}$ & 1.0 & 0.998 & \\
\hline
\end{tabular}

$R^{2}$ : correlation coefficient

$T_{i}, T_{p}$ and $T_{f}$ express the initial, peak and final temperature of $V M$ release

-: not available

Kinetic evaluation in the pyrolysis and gasification at heating rates of 5,10 , and $20^{\circ} \mathrm{C} \mathrm{min}^{-1}$ can be analyzed. It illustrates that as the heating rate is increased, no variation of the kinetic constants. In RS pyrolysis analysis, the activation energy obtained by the Arrhenius plot method was $75.4 \mathrm{~kJ} \mathrm{~mol}^{-1}$ for a heating rate of $10{ }^{\circ} \mathrm{C}$ $\min ^{-1}$. SS was observed to react faster during pyrolysis compared to RS. The lower activation energy was found at $49.1 \mathrm{~kJ} \mathrm{~mol}^{-1}$, due to the slightly higher amount of ash in SS. This conclusion is consistent with the 
Table 3 Kinetic constants for pyrolysis and gasification at different heating rates

\begin{tabular}{|c|c|c|c|c|c|c|}
\hline \multirow[t]{2}{*}{ Items } & \multicolumn{3}{|c|}{ Pyrolysis ( $\mathrm{N}_{2}$ atmosphere) } & \multicolumn{3}{|c|}{ Gasification (air atmosphere) } \\
\hline & Temp range $\left({ }^{\circ} \mathrm{C}\right)$ & Thermal decomposition rate & $\mathrm{R}^{2}$ & Temp range $\left({ }^{\circ} \mathrm{C}\right)$ & Thermal decomposition rate & $\mathrm{R}^{2}$ \\
\hline \multicolumn{7}{|c|}{ Heating rate $5^{\circ} \mathrm{C} \mathrm{min}^{-1}$} \\
\hline SS & $147-522$ & $k=7.77 \times 10^{4} e^{47.78 / R T}(X)^{2.62}$ & 0.91 & $137-529$ & $k=1.54 \times 10^{5} e^{61.01 / R T}(X)^{3.79}$ & 0.84 \\
\hline 20RS:80SS & $153-521$ & $k=5.82 \times 10^{4} e^{49.08 / R T}(X)^{1.75}$ & 0.88 & $145-568$ & $k=0.82 \times 10^{5} e^{59.45 / R T}(X)^{2.47}$ & 0.80 \\
\hline 40RS:60SS & $148-513$ & $k=2.56 \times 10^{4} e^{48.62 / R T}(X)^{0.84}$ & 0.84 & $151-521$ & $k=1.11 \times 10^{7} e^{78.76 / R T}(X)^{4.21}$ & 0.86 \\
\hline 50RS:50SS & $148-521$ & $k=5.75 \times 10^{4} e^{52.51 / R T}(X)^{0.74}$ & 0.84 & $163-519$ & $k=1.39 \times 10^{6} e^{69.74 / R T}(X)^{2.71}$ & 0.79 \\
\hline RS & $151-522$ & $k=8.56 \times 10^{6} e^{72.65 / R T}(X)^{1.35}$ & 0.87 & $179-503$ & $k=5.87 \times 10^{7} e^{87.15 / R T}(X)^{2.0}$ & 0.74 \\
\hline \multicolumn{7}{|c|}{ Heating rate $10^{\circ} \mathrm{C} \mathrm{min}^{-1}$} \\
\hline SS & $153-517$ & $k=1.37 \times 10^{5} e^{49.10 / R T}(X)^{2.41}$ & 0.90 & $148-550$ & $k=1.97 \times 10^{5} e^{60.12 / R T}(X)^{3.57}$ & 0.84 \\
\hline 20RS:80SS & $173-535$ & $k=0.71 \times 10^{5} e^{48.62 / R T}(X)^{1.52}$ & 0.86 & $154-659$ & $k=5.40 \times 10^{5} e^{63.73 / R T}(X)^{3.30}$ & 0.81 \\
\hline 40RS:60SS & $154-515$ & $k=0.84 \times 10^{5} e^{50.61 / R T}(X)^{0.9}$ & 0.84 & $160-551$ & $k=14.4 \times 10^{5} e^{64.31 / R T}(X)^{2.45}$ & 0.78 \\
\hline 50RS:50SS & $147-516$ & $k=1.44 \times 10^{5} e^{53.07 / R T}(X)^{0.69}$ & 0.83 & $160-551$ & $k=19.1 \times 10^{5} e^{68.66 / R T}(X)^{2.26}$ & 0.80 \\
\hline RS & $178-500$ & $k=18.6 \times 10^{6} e^{75.40 / R T}(X)^{1.43}$ & 0.82 & $166-534$ & $k=0.59 \times 10^{8} e^{89.56 / R T}(X)^{2.12}$ & 0.71 \\
\hline \multicolumn{7}{|c|}{ Heating rate $20^{\circ} \mathrm{C} \mathrm{min}^{-1}$} \\
\hline SS & $158-560$ & $k=3.47 \times 10^{5} e^{50.47 / R T}(X)^{2.32}$ & 0.91 & $153-532$ & $k=8.77 \times 10^{5} e^{64.65 / R T}(X)^{3.39}$ & 0.84 \\
\hline 20RS:80SS & $156-531$ & $k=1.67 \times 10^{5} e^{51.20 / R T}(X)^{1.51}$ & 0.90 & $168-615$ & $k=5.38 \times 10^{5} e^{63.36 / R T}(X)^{2.64}$ & 0.80 \\
\hline 40RS:60SS & $157-550$ & $k=0.84 \times 10^{5} e^{50.61 / R T}(X)^{0.90}$ & 0.84 & $177-550$ & $k=1.09 \times 10^{7} e^{75.28 / R T}(X)^{3.35}$ & 0.80 \\
\hline 50RS:50SS & $152-560$ & $k=1.58 \times 10^{5} e^{55.1032 / R T}(X)^{1.0}$ & 0.80 & $175-573$ & $k=8.91 \times 10^{6} e^{73.86 / R T}(X)^{2.82}$ & 0.80 \\
\hline RS & $150-548$ & $k=3.82 \times 10^{7} e^{74.01 / R T}(X)^{0.84}$ & 0.80 & $190-515$ & $k=1.62 \times 10^{8} e^{88.09 / R T}(X)^{1.90}$ & 0.70 \\
\hline
\end{tabular}

$R^{2}$ in a multiple regression model

previous published literature result that reduced the activation energy from 87.7 to $51.6 \mathrm{~kJ} \mathrm{~mol}^{-1}$ by adding oil-palm solid wastes into paper sludge under pyrolysis conditions [22]. The higher activation energies were obtained for gasification 89.6 and $60.1 \mathrm{~kJ} \mathrm{~mol}^{-1}$ in RS and SS, respectively. RS was found to be more reactive to gasification compared to SS. This is due to the relatively higher amount of VM in RS compared to SS. Highly reactive combustible components may account for the high reactivity towards gasification by SS samples. As shown in Table 3, the activation energy increases with increasing RS addition in the $48.6-53.1 \mathrm{~kJ}$ $\mathrm{mol}^{-1}$ range in pyrolysis and $63.7-68.7 \mathrm{~kJ} \mathrm{~mol}^{-1}$ under gasification conditions with 20 to $50 \mathrm{wt} \%$ addition ratios.

In the multiple regression model, the multiple correlation coefficient $\left(R^{2}\right)$ value indicates the dependent variable relation (activation energy) and two other predictor variables (pre-exponential and reaction order). Table 3 shows the coefficient of multiple correlations are in the region of $0.7-0.9$ and is not a measure of the straightline model appropriateness. The linear regression establishing the relationship between the fitted line and all of the activation energy and time function data points. The strong correlation coefficients have partial correlation $\left(\mathrm{R}^{2}\right)$ in the $0.9-0.99$ range and decrease slightly by adding one more variable (reaction order). The reaction order values were different from stage to stage and changed with different fuel mixing ratios.
The RS and their blends exponential factors were in the $0.71 \times 10^{5}-18.6 \times 10^{6}\left(\mathrm{~min}^{-1}\right)$ pyrolysis condition range. Higher pre-exponential values were found in the gasification simulation, with the higher estimated value in the $1.97 \times 10^{5}-0.59 \times 10^{8}\left(\mathrm{~min}^{-1}\right)$ range, respectively. That can be explained by oxidation reactions occurring after the gasification process, from reaction by-products that include syngas, char and tar production. Tar product is decomposed due to the presence of oxygen, making the thermal decomposition process longer than pyrolysis. The results were also confirmed by previous published literature [36, 37]. Similar phenomena occurred in this research with higher activation energy found under gasification conditions, due to highly reactive ash components. Comparison of different atmospheres, it leads to the conclusion that an increasing tendency in the increasing degree of oxidation causes the increases in the degradation rates and shifts the decomposition of non-biodegradable matter to lower temperatures, due to a more exothermal balance.

\section{Characterization of the gas evolution during the co- thermal degradation of RS and SS}

Figure 3a shows the 3D FTIR diagram of the RS pyrolysis process with a heating rate of $10^{\circ} \mathrm{C} \mathrm{min}^{-1}$. The results indicated that four pyrolysis stages occur at the temperature ranges of $40-178,179-319,320-500^{\circ} \mathrm{C}$, and above $500^{\circ} \mathrm{C}$. Figure $3 \mathrm{~b}$ displays the observed 

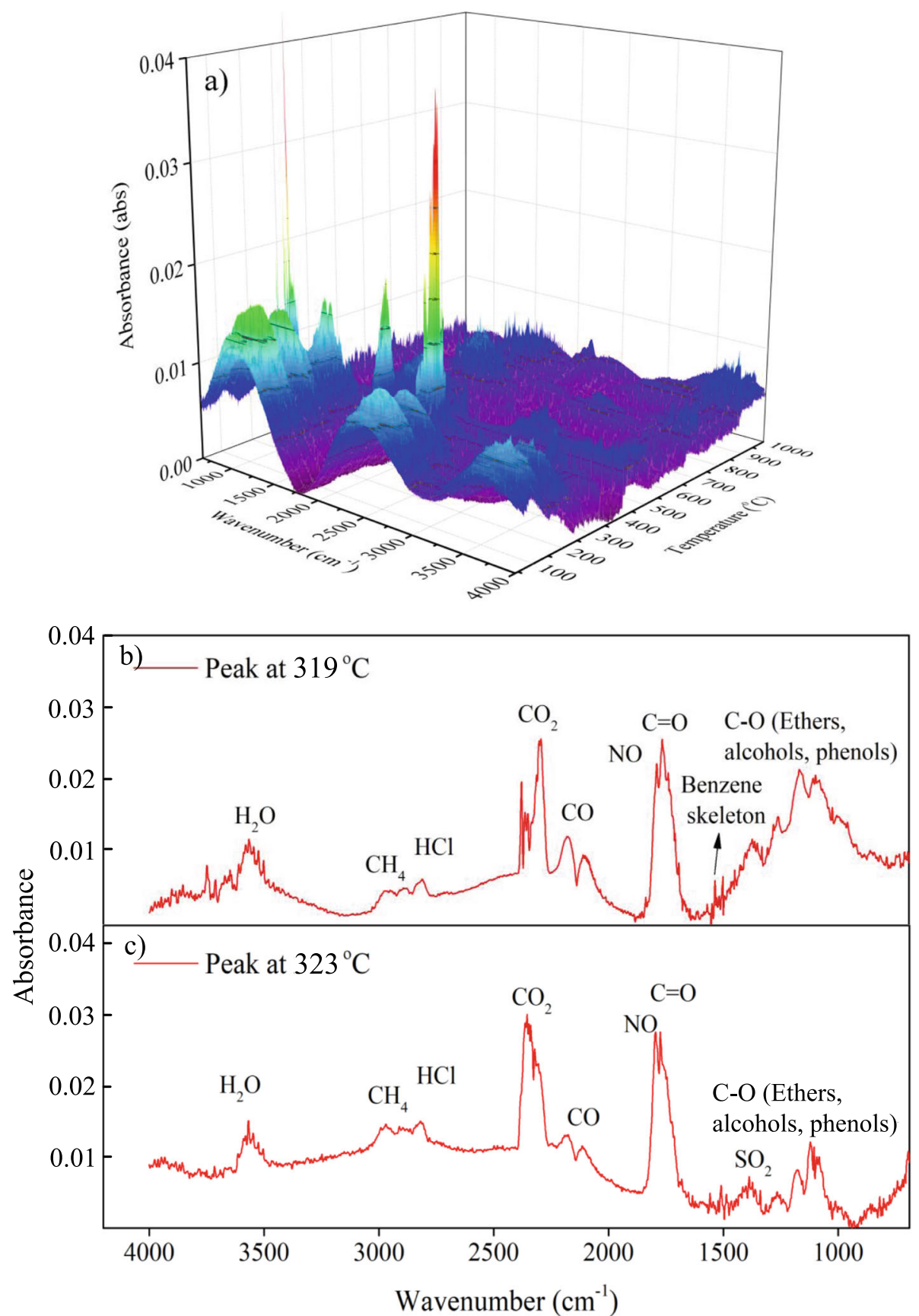

Fig. 3 Analysis showing a) 3D FTIR diagram b) FTIR spectrum for volatiles in pyrolysis c) FTIR spectrum for volatiles in gasification of rice straw with a heating rate of $10^{\circ} \mathrm{C} \mathrm{min}^{-1}$

change in the FTIR spectra during the RS pyrolysis process. The main gas phases that occur in pyrolysis include $\mathrm{CO}, \mathrm{CO}_{2}, \mathrm{CH}_{4}, \mathrm{HCl}$, aldehyde, $\mathrm{CH}_{3} \mathrm{COOH}$, phenol, and methanol. Based on the results obtained from TG-DTG curves (as shown in Fig. 2), the results showed the chemical reaction occurs in changes from one phase to others, either the endothermic reaction (usually for melting) or exothermic reaction (e.g., crystallization, release some energies). The first stage is related to the dewatering process (moisture content evaporation) from the start of run 40 to $178^{\circ} \mathrm{C}$. During this stage, the amount of water vapor increases, and the identifiable gaseous product is water. The initial peaks at 1750 $1250 \mathrm{~cm}^{-1}$ and $4000-3200 \mathrm{~cm}^{-1}$ represent moisture within the biomass and sludge as detailed by the published literature $[15,30,43-47]$. The second stage 
corresponds to biomass decarboxylation and oxidation. When the temperature is higher than $151{ }^{\circ} \mathrm{C}$, the $\mathrm{RS}$ chemical structure starts to change dramatically. Some gaseous products are detected in this stage, such as $\mathrm{CO}_{2}$, $\mathrm{CO}, \mathrm{CH}_{4}$, and water vapor. The band at $2920 \mathrm{~cm}^{-1}$ represents $\mathrm{C}-\mathrm{H}$ stretching. The band at 2350 and 2250 $\mathrm{cm}^{-1}$ is assigned to the carbonyl $(\mathrm{C}=\mathrm{O})$ stretching. Carbonyls mainly exist in the side chains of lignin structural units. The band near $3000-2600 \mathrm{~cm}^{-1}$ can be described as $\mathrm{C}-\mathrm{H}$ bending in cellulose and hemicellulose. The peak at $2250-2000 \mathrm{~cm}^{-1}$ is indicative of $\mathrm{C}-\mathrm{O}$ stretching.

The TGA-FTIR spectra for RS demonstrate characteristic peaks involved in the representative of $\mathrm{SO}_{2}$. The literature results reported the aromatic compounds at the absorbance wavenumber of 1342 and $1600-1450 \mathrm{~cm}^{-1}$ [48]. This suggests that the second stage was mainly responsible for the initial decomposition of RS contaminants. On the other hand, $\mathrm{SO}_{2}$ was found in $\mathrm{RS}$ gasification due to the sulfur containing in the RS gasified at partial oxidation atmosphere. When the operation temperature was reached to $500{ }^{\circ} \mathrm{C}$, almost all functional groups are eliminated due to organic matter decomposition. Gaseous products were generated, such as $\mathrm{H}_{2} \mathrm{O}$, $\mathrm{CH}_{4}$, and phenol $\left(\mathrm{C}_{6} \mathrm{H}_{5} \mathrm{OH}\right)$, that would be further decomposed in the third stage. According to the analysis results of TGA-FTIR, the evolution of gaseous products increases with the temperature, reaching their maximum values between 178 and $500^{\circ} \mathrm{C}$. At the higher temperature range from 500 to $1000^{\circ} \mathrm{C}$, the release of pollutant gases is almost negligible due to the completion of pyrolysis reaction.

TG-FTIR is also a good technique for determining the different gaseous species existing during different thermal decomposition processes. Figure 3c showed the gas evolution in the RS gasification. Gasification is a partly oxidizing process that converts biomass into useful energy such as syngas, which contributes to developing hydrogen, methanol, and synthetic fuels [49]. The gasification process gas is injected into the TGA-FTIR. The IR spectra results show that more $\mathrm{CO}, \mathrm{CO}_{2}$ products are measured under the operating condition. That can be explained using the following reactions $\left(R_{1}-R_{3}\right)$ :

$$
\begin{aligned}
& \mathrm{C}+1 / 2 \mathrm{O}_{2} \rightarrow \mathrm{CO} \text { Carbon partial oxidation } \\
& \mathrm{CO}+1 / 2 \mathrm{O}_{2} \rightarrow \mathrm{CO}_{2} \text { Carbon monoxide oxidation } \\
& \mathrm{C}+\mathrm{O}_{2} \rightarrow \mathrm{CO}_{2} \text { Carbon oxidation }
\end{aligned}
$$

The major producer gases in RS gasification, including $\mathrm{CO}_{2}, \mathrm{CO}, \mathrm{CH}_{4}, \mathrm{HCl}, \mathrm{SO}_{2}, \mathrm{NO}$, ether, alcohol, and phenol, were a little bit different with that of producer gases in pyrolysis. The two highest peaks were found at 319 and $323^{\circ} \mathrm{C}$ corresponding with the FTIR spectrum for volatiles in RS gasification. Partial air oxidation reaction could promote the reaction rate. In this research, FTIR spectrum for volatiles in RS pyrolysis also showed a peak at wavenumber $1618 \mathrm{~cm}^{-1}$ which represented aromatic skeletal vibration. This is because pyrolytic products mainly produced from volatiles and tar cracking during RS pyrolysis. It implied that some of condensable, non-condensable, and polycyclic aromatic hydrocarbons could be presented in the pyrolytic products. The results were confirmed by previous investigators [13]. On the other hand, the higher and broader peak related to organic hydrocarbon compounds, such as C-O stretching at wavenumber as $1300-950 \mathrm{~cm}^{-1}$, was found in RS pyrolysis. This could explain that some interactions existed such as hydrogen bonding interaction. Therefore, if the peak is broader, it could mean the number of bonds occurs in the gas product must be considered. More tar (oil) is generated by pyrolysis compared with gasification.

The FTIR spectrum indicated the gases generated during RS and SS mixture pyrolysis (RS proportion from 0 to $50 \%$ as a function of both wavenumber and temperature). Figure $4 \mathrm{a}$ illustrates that the gases evolution of the 3D FTIR diagram in pyrolysis of SS only ( $0 \%$ of RS) and mixtures with 20,40 , and $50 \%$ of RS. The main volatile components in organic compounds identified by FTIR were aliphatic chains with double bonds accompanying $\mathrm{C}=\mathrm{O}, \mathrm{OH}-$, and $\mathrm{C}-\mathrm{H}$ groups. The major functional groups and gaseous species were measured in the pyrolysis reaction, including $\mathrm{C}=\mathrm{O}$ stretching $\left(2400-2250 \mathrm{~cm}^{-1}\right), \mathrm{C}-\mathrm{O}$ stretching (2240$\left.2000 \mathrm{~cm}^{-1}\right)$, C-H stretching $\left(3000-2600 \mathrm{~cm}^{-1}\right), \mathrm{O}-\mathrm{H}$ $\left(4000-3500 \mathrm{~cm}^{-1}\right), \mathrm{HCl}\left(2789 \mathrm{~cm}^{-1}\right)$, and $\mathrm{NH}_{3}(850-$ $\left.736 \mathrm{~cm}^{-1}\right)$. During the pyrolysis process, specific chemical compounds, such as syngas, aldehyde, $\mathrm{HCl}$, and $\mathrm{NH}_{3}$, were determined by TGA-FTIR. This is due to the chlorine and nitrogen content existence in RS that were partially converted to hydrogen chloride $(\mathrm{HCl})$ and ammonia $\left(\mathrm{NH}_{3}\right)$. Figure $4 \mathrm{~b}$ shows the TGA-FTIR spectrograms representing characteristic absorption bands within the $1700-800 \mathrm{~cm}^{-1}$ region, such as acetic acid, toluene, phenol, and formic acid. The presence of $\mathrm{NH}_{3}$, $\mathrm{HCl}$ and other acid gases detected by TGA-FTIR was also confirmed by previous pyrolysis works $[45,50]$. Figure $4 \mathrm{c}$ illustrates clearly the characteristic infrared absorption peaks of the volatile components. It is observed that absorbance increases with higher gas concentration when the RS mixing ratio is increased from 0 to $40 \%$. It implies that increasing the RS mixing ratio up to $40 \%$ increases the concentration of the gaseous product. However, in the case of the RS content further increasing from 40 to $50 \%$, the gaseous products seem to be decreased due to the corresponding lower absorbance. This is because the hydrocarbon reformation and/or watergas shift reactions could be inhibited. Besides, ash 

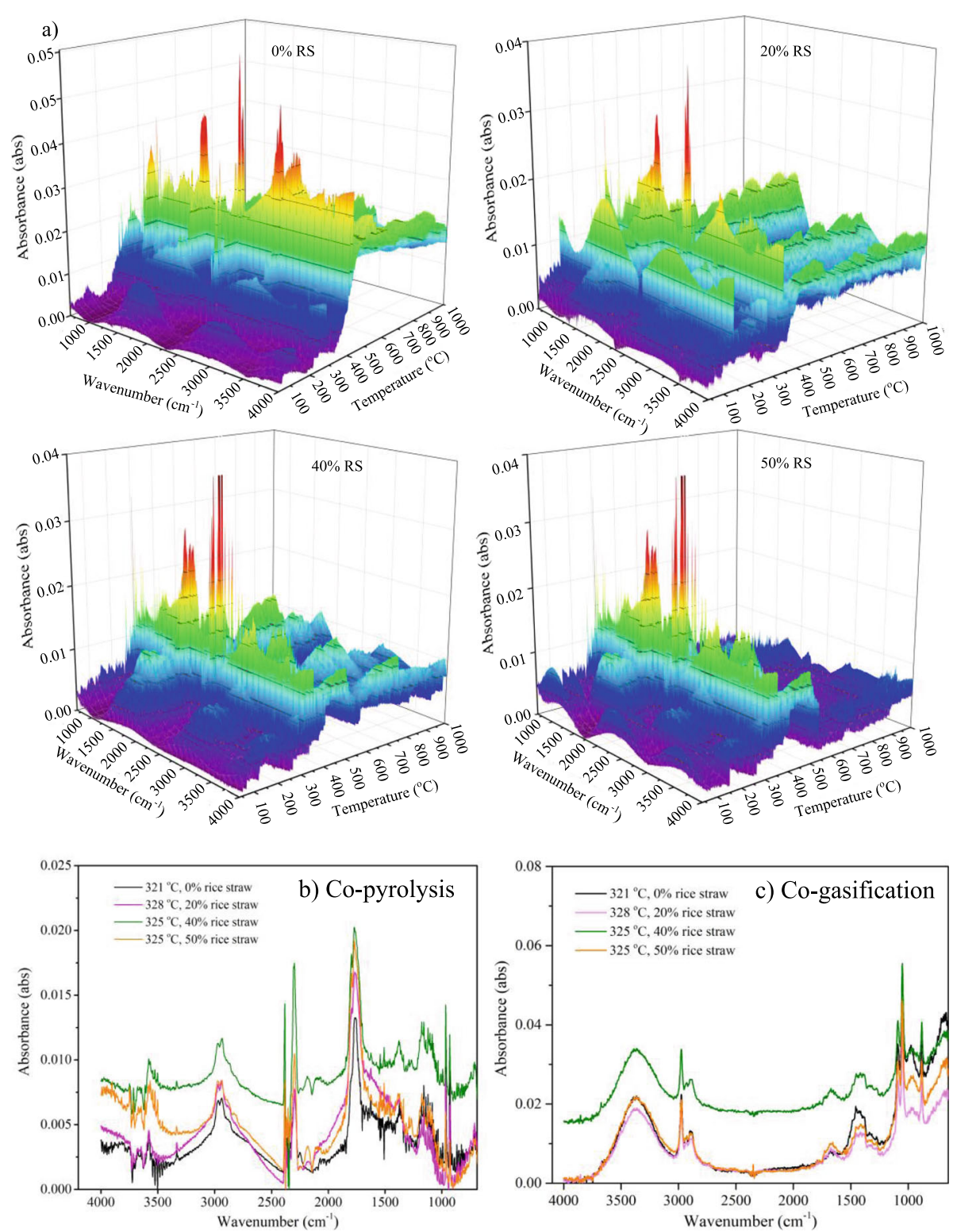

Fig. 4 Analysis showing a) 3D FTIR diagram b) FTIR adsorption spectra of as released from sewage sludge, and their mixtures with rice straw as detected by TGA-FTIR in co-pyrolysis and $\mathbf{c}$ ) in co-gasification

agglomeration could coour and block oxygen diffusion into the char particles due to the RS containing a high potassium and silicon concentration [51]. The $\mathrm{O}-\mathrm{H}$ bond vibrations (stretching and bending) are represented along the wide band from 3000 to $4000 \mathrm{~cm}^{-1}$ and the peak situated at $1650 \mathrm{~cm}^{-1}$ (as shown in Fig. 4c). These bonds denote the presence of water. These vibrations are more intense after co-gasifcation reactions, suggests the water formation. It could be supposed that some chemical reactions produced water [52]. The reduction reactions lead to the formation of methane or syngas $\left(\mathrm{CO}+\mathrm{H}_{2}\right)$. The tar, char, and volatile substances produced by the aforementioned pyrolysis are subjected to the effects of water gas reaction, water gas shift reaction, and methanation reaction. The spectrograms exhibiting characteristic absorption bands within the 2700-3000 $\mathrm{cm}^{-1}$ regions, corespond to the existence of methane $\left(\mathrm{CH}_{4}\right)$.

Table 4 displays the detected gaseous species adsorption bands during pyrolysis and further presents a comparison between the present study and those of others using TG-FTIR [8-10, 24, 38-40]. The waste materials (biomass and sludge) pyrolysis process presents $\mathrm{CO}_{2} \mathrm{CO}, \mathrm{CH}_{4}, \mathrm{CH}_{3} \mathrm{COOH}, \mathrm{HCOOH}$, methanol, phenol, and esters as the main gaseous species produced. The RS chemical structure indicated that the abundant 
Table 4 Gaseous species based on wavenumbers $\left(\mathrm{cm}^{-1}\right)$ and functional groups for pyrolysis studies

\begin{tabular}{|c|c|c|c|c|c|c|}
\hline Sample & $\begin{array}{l}\text { Wavenumber range } \\
\left(\mathrm{cm}^{-1}\right)\end{array}$ & $\begin{array}{l}\text { Peak } \\
\left(\mathrm{cm}^{-1}\right)\end{array}$ & Species & $\begin{array}{l}\text { Functional } \\
\text { group }\end{array}$ & Vibration & Ref. \\
\hline $\mathrm{RS}, \mathrm{SS}$, and their blend & $2375-2250$ & 2350,2250 & $\mathrm{CO}_{2}$ & $\mathrm{C}=\mathrm{O}$ & Stretching & $\begin{array}{l}\text { This } \\
\text { study }\end{array}$ \\
\hline Wood, plastic, tire, and RDF & $2400-2250$ & 2350 & & & & {$[15]$} \\
\hline Spruce and pine biomass & $2400-2240$ & 2359,2322 & & & & {$[30]$} \\
\hline Straw with absorbed glycerol & $2400-2240$ & 2360 & & & & {$[44]$} \\
\hline $\begin{array}{l}\text { Solid waste, paper mill sludge, and their } \\
\text { blends }\end{array}$ & $2400-2240$ & & & & & {$[45]$} \\
\hline Marine sediment & $2400-2240$ & & & & & [17] \\
\hline Palm kernel shell from palm oil & $2400-2250$ & & & & & {$[46]$} \\
\hline $\mathrm{RS}, \mathrm{SS}$, and their blend & $2167-2120$ & 2170 & $\mathrm{CO}$ & $\mathrm{C}-\mathrm{O}$ & Stretching & $\begin{array}{l}\text { This } \\
\text { study }\end{array}$ \\
\hline Wood, plastic, tire, and RDF & $2250-2000$ & 2110,2200 & & & & [15] \\
\hline Coals, sawdust, RS, and corn stalk & $2240-2027$ & & & & & [16] \\
\hline Palm kernel shell from palm oil & $2250-2000$ & & & & & {$[46]$} \\
\hline $\begin{array}{l}\text { Solid waste, paper mill sludge, and their } \\
\text { blends }\end{array}$ & & 2178 & & & & {$[45]$} \\
\hline Marine sediment & $2240-2060$ & & & & & [17] \\
\hline $\mathrm{RS}, \mathrm{SS}$, and their blend & $3000-2600$ & 2920 & $\mathrm{CH}_{4}$ & $\mathrm{C}-\mathrm{H}$ & Stretching & $\begin{array}{l}\text { This } \\
\text { study }\end{array}$ \\
\hline Wood, plastic, tire, and RDF & & 2930 & & & & {$[15]$} \\
\hline Spruce and pine biomass & $3000-2600$ & 2897,2821 & & & & {$[30]$} \\
\hline Coals, sawdust, RS, and corn stalk & $3045-2875$ & & & & & [16] \\
\hline Palm kernel shell from palm oil & $3000-2700$ & & & & & {$[46]$} \\
\hline Straw with absorbed glycerol & & 3100 & & & & {$[44]$} \\
\hline $\begin{array}{l}\text { Solid waste, paper mill sludge, and their } \\
\text { blends }\end{array}$ & $3100-2850$ & 3016 & & & & {$[45]$} \\
\hline Marine sediment & $3000-2880$ & & & & & {$[17]$} \\
\hline $\mathrm{RS}, \mathrm{SS}$, and their blend & $3964-3500$ & 3800,3600 & $\mathrm{H}_{2} \mathrm{O}$ & $\mathrm{O}-\mathrm{H}$ & Stretching & $\begin{array}{l}\text { This } \\
\text { study }\end{array}$ \\
\hline Wood, plastic, tire, and RDF & $4000-3500$ & & & & & {$[15]$} \\
\hline Coals, sawdust, RS, and corn stalk & $1750-1250$ & & & & & [16] \\
\hline Palm kernel shell from palm oil & $4000-3400$ & & & & & {$[46]$} \\
\hline Straw with absorbed glycerol & $4000-3600$ & & & & & [44] \\
\hline $\begin{array}{l}\text { Solid waste, paper mill sludge, and their } \\
\text { blends }\end{array}$ & $4000-3500$ & & & & & {$[45]$} \\
\hline Spruce and pine biomass & $3900-3200$ & 3853,3568 & & & & {$[30]$} \\
\hline $\mathrm{RS}, \mathrm{SS}$, and their blend & $1900-1600$ & 1750,1720 & $\mathrm{CH}_{3} \mathrm{COOH}$ & $\mathrm{C}-\mathrm{O}(\mathrm{H})$ & & $\begin{array}{l}\text { This } \\
\text { study }\end{array}$ \\
\hline Wood, plastic, tire, and RDF & $1900-1600$ & & & $\mathrm{C}=\mathrm{O}$ & Stretching & {$[15]$} \\
\hline Spruce and pine biomass & $1845-1500$ & 1768,1745 & & & & [30] \\
\hline Coals, sawdust, RS, and corn stalk & $1900-1603$ & & & & & [16] \\
\hline Palm kernel shell from palm oil & 1900-1650 & & & & & [46] \\
\hline $\begin{array}{l}\text { Solid waste, paper mill sludge, and their } \\
\text { blends }\end{array}$ & $1850-1600$ & & & & & {$[45]$} \\
\hline $\mathrm{RS}, \mathrm{SS}$, and their blend & $1200-1100$ & 1120 & $\mathrm{HCOOH}$ & $\mathrm{C}-\mathrm{O}(\mathrm{H})$ & Stretching & $\begin{array}{l}\text { This } \\
\text { study }\end{array}$ \\
\hline Wood, plastic, tire, and RDF & & 1400,1745 & & & & {$[15]$} \\
\hline
\end{tabular}


Table 4 Gaseous species based on wavenumbers $\left(\mathrm{cm}^{-1}\right)$ and functional groups for pyrolysis studies (Continued)

\begin{tabular}{|c|c|c|c|c|c|c|}
\hline Sample & $\begin{array}{l}\text { Wavenumber range } \\
\left(\mathrm{cm}^{-1}\right)\end{array}$ & $\begin{array}{l}\text { Peak } \\
\left(\mathrm{cm}^{-1}\right)\end{array}$ & Species & $\begin{array}{l}\text { Functional } \\
\text { group }\end{array}$ & Vibration & Ref. \\
\hline Coals, sawdust, RS, and corn stalk & $1200-1100$ & & & & & [16] \\
\hline $\mathrm{RS}, \mathrm{SS}$, and their blend & $1400-1200$ & 1320. 1250 & $\mathrm{C}_{6} \mathrm{H}_{5} \mathrm{OH}$ (Phenol) & $\mathrm{O}-\mathrm{H}$ & Bending & $\begin{array}{l}\text { This } \\
\text { study }\end{array}$ \\
\hline Wood, plastic, tire, and RDF & & 1100,1300 & & & & {$[15]$} \\
\hline Spruce and pine biomass & $1500-1325$ & 1373 & & & & [30] \\
\hline Coals, sawdust, RS, and corn stalk & $1400-1200$ & & & & & [16] \\
\hline Palm kernel shell from palm oil & $1300-1200$ & & & $\mathrm{C}-\mathrm{O}$ & stretching & {$[46]$} \\
\hline $\mathrm{RS}, \mathrm{SS}$, and their blend & $1279-1100$ & 1100 & $\begin{array}{l}\mathrm{CH}_{3} \mathrm{OH} \\
\text { (Methanol) }\end{array}$ & $\mathrm{O}-\mathrm{H}$ & Blending & $\begin{array}{l}\text { This } \\
\text { study }\end{array}$ \\
\hline Wood, plastic, tire, and RDF & $3000-2900$ & & & & & [15] \\
\hline Spruce and pine biomass & 1300-950 & 1165,1120 & & $\mathrm{C}-\mathrm{O}$ & Stretching & [30] \\
\hline Palm kernel shell from palm oil & $1200-1000$ & & & & & {$[46]$} \\
\hline Straw with absorbed glycerol & $1130-1030$ & 1055 & & & & [44] \\
\hline $\mathrm{RS}, \mathrm{SS}$, and their blend & $1600-1450$ & 1470 & Aromatic & $\mathrm{C}-\mathrm{H}$ & Bending & $\begin{array}{l}\text { This } \\
\text { study }\end{array}$ \\
\hline Spruce and pine biomass & $1000-650$ & 669,642 & & & & [30] \\
\hline Palm kernel shell from palm oil & $1690-1450$ & & & $C=C$ & Stretching & [46] \\
\hline Marine sediment & $1600-1420$ & & & & & [17] \\
\hline $\begin{array}{l}\text { Solid waste, paper mill sludge, and their } \\
\text { blends }\end{array}$ & $1850-1600$ & & Aldehyde & $\mathrm{C}=\mathrm{O}$ & Stretching & {$[45]$} \\
\hline Straw with absorbed glycerol & & 1720 & & & & {$[44]$} \\
\hline Marine sediment & $1700-1600$ & & & & & \\
\hline Palm kernel shell from palm oil & $1460-1365$ & & Alkanes & $\mathrm{C}-\mathrm{C} ; \mathrm{C}-\mathrm{H}$ & Stretching & {$[46]$} \\
\hline Marine sediment & $850-736$ & & $\mathrm{NH}_{3}$ & & & [16] \\
\hline
\end{tabular}

RDF Refuse-derived fuel

chemical bonds were $\mathrm{O}-\mathrm{H}, \mathrm{C}-\mathrm{H}, \mathrm{C}=\mathrm{C}$ and $\mathrm{C}-\mathrm{O}$, and aromatic $\mathrm{C}=\mathrm{C} / \mathrm{C}-\mathrm{H}$. It implied that the aromatic compounds formation was probably condensed during the pyrolysis process which were determined as aromatic $\mathrm{C}$ $\mathrm{H}$ bond bending (wavenumber was between 2000 and $1660 \mathrm{~cm}^{-1}$ ) [41]. The literature results also proved that some weak peaks were representing aromatic hydrocarbon in the $1400-1000 \mathrm{~cm}^{-1}$ range [40]. Based on the TG-FTIR analysis results, the main groups in the RS were aliphatic chains with double bonds, as well as carbonyl $(\mathrm{C}=\mathrm{O})$, hydroxyl $(\mathrm{O}-\mathrm{H})$, alkane $(\mathrm{C}-\mathrm{H})$ and alkyl amine. In summary, the experimental results suggested that RS at the mixing ratio of $40 \mathrm{wt} \%$ with $60 \mathrm{wt} \% \mathrm{SS}$ could be the optimum conditions in co-thermal treatment. From the kinetic analysis results, RS and SS cogasification can reduce the required activation energy and enhance the reaction rate. This study discussed how mixing RS with SS could simulate the pyrolysis and gasification process and quantitatively analyze the gaseous components. Further studies are necessary to understand the FTIR that gives reliable quantitative information regarding the functional groups present.

\section{Conclusions}

The co-pyrolysis/gasification characteristics and kinetic analysis with or without SS, RS, and their blends additives under different heating rates using TG-FTIR were studied. The results obtained in this research were given as follows. From the TG and DTG analysis of RS, SS, and their blends, it was found that SS is decomposed at a lower temperature than RS. The temperature range of VM devolatilization is broader when the extra RS amount is added. RS has a significant influence on the VM released in co-pyrolysis/gasification. Activation energy calculated using the Arrhenius equation could increase from $48.6-53.1 \mathrm{~kJ} \mathrm{~mol}^{-1}$ in a linearly correlating behavior with increasing RS addition. The exponential factors of RS and their blends under the pyrolysis condition ranged from $0.71 \times 10^{5}-18.6 \times 10^{6}\left(\mathrm{~min}^{-1}\right)$. TGAFTIR revealed a series of organic species (the gaseous volatile) containing moisture, $\mathrm{CO}_{2}, \mathrm{CO}, \mathrm{CH}_{4}$, acidic gases, and aromatic compounds. In addition, this study also proved that the RS co-pyrolysis/gasification process imposed a significant impact on gaseous pollutants production $\left(\mathrm{CO}_{2}, \mathrm{NO}\right.$, and $\left.\mathrm{SO}_{2}\right)$. This is an astounding 
acknowledgment for the co-thermal treatment of partial oxidation performance for some blends. The main volatile components identified by FTIR were aliphatic chains with double bonds, as well as carbonyl, hydroxyl, and $\mathrm{C}-\mathrm{H}$ groups. In particular, functional groups and gaseous species contributed to the entire pyrolysis reaction were: $\mathrm{C}=\mathrm{O}$ stretching $\left(2400-2250 \mathrm{~cm}^{-1}\right), \mathrm{C}-\mathrm{O}$ stretching $\left(2240-2000 \mathrm{~cm}^{-1}\right), C-\mathrm{H}$ stretching $\left(3000-2600 \mathrm{~cm}^{-1}\right)$, $\mathrm{O}-\mathrm{H} \quad\left(4000-3500 \mathrm{~cm}^{-1}\right)$, and $\mathrm{SO}_{2}\left(1350-1342 \mathrm{~cm}^{-1}\right)$, $\mathrm{HCl}\left(2798-2789 \mathrm{~cm}^{-1}\right), \quad \mathrm{NO}\left(1762 \mathrm{~cm}^{-1}\right)$ and $\mathrm{NH}_{3}$ $\left(850-736 \mathrm{~cm}^{-1}\right)$. The experimental results show that RS at $40 \mathrm{wt} \%$ mixed with $60 \mathrm{wt} \% \mathrm{SS}$ was the optimum cothermal treatment proportion. In summary, by exploiting such information, operators or designers can choose a suitable condition for running pyrolysis/gasification in commercial-scale plant in the future.

\section{Acknowledgments}

The authors would like to express their appreciation and gratitude to the Ministry of Science and Technology (MOST) (Project No. MOST-107-2621-M008-003). The authors also would like to thanks the Precision Instrument Support Center of National Central University in providing the analysis facilities.

\section{Authors' contributions}

The manuscript draft was interpreted and written by Dr. Thi Ngoc Lan Thao Ngo. Prof. Kung-Yuh Chiang provided technical support, revised the manuscript, and also supervised the research. All authors read and approved the final manuscript.

\section{Funding}

This work was supported by Ministry of Science and Technology (MOST) (Project No. MOST-107-2621-M-008-003).

\section{Availability of data and materials}

The datasets supporting the conclusions of this article are included within the article.

\section{Declaration}

\section{Competing interests}

The authors declare they have no competing interests.

Received: 30 December 2020 Accepted: 6 June 2021

Published online: 26 June 2021

\section{References}

1. Chen YC, Kuo J. Potential of greenhouse gas emissions from sewage sludge management: a case study of Taiwan. J Clean Prod. 2016;129:196-201.

2. Chang SS, Lee WJ, Holsen TM, Li HW, Wang LC, Chang-Chien GP. Emissions of polychlorinated-p-dibenzo dioxin, dibenzofurans (PCDD/Fs) and polybrominated diphenyl ethers (PBDEs) from rice straw biomass burning. Atmos Environ. 2014:94:573-81.

3. Arena U. Process and technological aspects of municipal solid waste gasification. A review. Waste Manage. 2012;32:625-39.

4. Hu M, Gao L, Chen ZH, Ma CF, Zhou Y, Chen J, et al. Syngas production by catalytic in-situ steam co-gasification of wet sewage sludge and pine sawdust. Energ Convers Manage. 2016;111:409-16.

5. Chen YH, Ngo TNLT, Chiang KY. Enhanced hydrogen production in cogasification of sewage sludge and industrial wastewater sludge by a pilotscale fluidized bed gasifier. Int J Hydrogen Energ. 2021;46:14083-95.

6. Thao NTNL, Chiang KY, Wan HP, Hung WC, Liu CF. Enhanced trace pollutants removal efficiency and hydrogen production in rice straw gasification using hot gas cleaning system. Int J Hydrogen Energ. 2019;44: 3363-72.
7. Chiang KY, Lu CH, Liao CK, Ger RHR. Characteristics of hydrogen energy yield by co-gasified of sewage sludge and paper-mill sludge in a commercial scale plant. Int J Hydrogen Energ. 2016;41:21641-8.

8. Chiang KY, Chien KL, Lu CH. Characterization and comparison of biomass produced from various sources: suggestions for selection of pretreatment technologies in biomass-to-energy. Appl Energ. 2012;100:164-71.

9. Goyal HB, Seal D, Saxena RC. Bio-fuels from thermochemical conversion of renewable resources: a review. Renew Sust Energ Rev. 2008;12:504-17.

10. Prins MJ, Ptasinski KJ, Janssen FJJG. More efficient biomass gasification via torrefaction. Energy. 2006;31:3458-70.

11. Mueller A, Haustein HD, Stoesser P, Kreitzberg T, Kneer R, Kolb T. Gasification kinetics of biomass- and fossil-based fuels: comparison study using fluidized bed and thermogravimetric analysis. Energ Fuel. 2015;29:6717-23.

12. Shen FH, Liu J, Dong YC, Gu CK. Insights into the effect of chlorine on arsenic release during MSW incineration: an on-line analysis and kinetic study. Waste Manage. 2018;75:327-32.

13. Yang JK, Xu XY, Liang S, Guan RN, Li HS, Chen Y, et al. Enhanced hydrogen production in catalytic pyrolysis of sewage sludge by red mud: thermogravimetric kinetic analysis and pyrolysis characteristics. Int J Hydrogen Energ. 2018;43:7795-807.

14. Tang YT, Ma XQ, Lai ZY, Yu QH. Oxy-fuel combustion characteristics and kinetics of microalgae and its mixture with rice straw using thermogravimetric analysis. Int J Energ Res. 2018;42:532-41.

15. Singh $\mathrm{S}$, Wu CF, Williams PT. Pyrolysis of waste materials using TGA-MS and TGA-FTIR as complementary characterisation techniques. J Anal Appl Pyrol. 2012;94:99-107.

16. Xu CF, Hu S, Xiang J, Zhang LQ, Sun LS, Shuai $C$, et al. Interaction and kinetic analysis for coal and biomass co-gasification by TG-FTIR. Bioresour Technol. 2014;154:313-21.

17. Oudghiri F, Allali N, Quiroga JM, Rodriguez-Barroso MR. TG-FTIR analysis on pyrolysis and combustion of marine sediment. Infrared Phys Techn. 2016;78: 268-74.

18. Nguyen VT, Chiang KY. Sewage and textile sludge thermal degradation kinetic study using multistep approach. Thermochim Acta. 2021;698:178871.

19. Reyes-Labarta JA, Marcilla A. Kinetic study of the decompositions involved in the thermal degradation of commercial azodicarbonamide. J Appl Polym Sci. 2008;107:339-46.

20. Mansaray KG, Ghaly AE. Determination of reaction kinetics of rice husks in air using thermogravimetric analysis. Energ Source. 1999;21: 899-911.

21. Bartocci P, Anca-Couce A, Slopiecka K, Nefkens S, Evic N, Retschitzegger S, et al. Pyrolysis of pellets made with biomass and glycerol: kinetic analysis and evolved gas analysis. Biomass Bioenerg. 2017;97:11-9.

22. Lin YS, Ma XQ, Ning XX, Yu ZS. TGA-FTIR analysis of co-combustion characteristics of paper sludge and oil-palm solid wastes. Energ Convers Manage. 2015;89:727-34.

23. Zhang SQ, Yue XM, Yin ZY, Pan TT, Dong MJ, Sun TY. Study of the copyrolysis behavior of sewage-sludge/rice-straw and the kinetics. Proced Earth Plan Sc. 2009;1:661-6.

24. Shao J, Yan R, Chen H, Wang B, Lee DH, Liang DT. Pyrolysis characteristics and kinetics of sewage sludge by thermogravimetry Fourier transform infrared analysis. Energ Fuel. 2008;22:38-45.

25. Piatkowski N, Steinfeld A. Reaction kinetics of the combined pyrolysis and steam-gasification of carbonaceous waste materials. Fuel. 2010;89:1133-40.

26. Wang S, Wang Q, Hu YM, Xu SN, He ZX, Ji HS. Study on the synergistic copyrolysis behaviors of mixed rice husk and two types of seaweed by a combined TG-FTIR technique. J Anal Appl Pyrol. 2015;114:109-18.

27. Parthasarathy P, Narayanan KS, Arockiam L. Study on kinetic parameters of different biomass samples using thermo-gravimetric analysis. Biomass Bioenerg. 2013;58:58-66.

28. El-Sayed SA, Mostafa ME. Kinetic parameters determination of biomass pyrolysis fuels using TGA and DTA techniques. Waste Biomass Valori. 2015;6: 401-15.

29. Raheem A, Dupont V, Channa AQ, Zhao X, Vuppaladadiyam AK, Taufiq-Yap $\mathrm{YH}$, et al. Parametric characterization of air gasification of chlorella vulgaris biomass. Energ Fuel. 2017:31:2959-69.

30. Salema AA, Afzal MT, Motasemi F. Is there synergy between carbonaceous material and biomass during conventional pyrolysis? A TG-FTIR approach. J Anal Appl Pyrol. 2014;105:217-26.

31. Wang GW, Zhang JL, Shao JG, Sun H, Zuo HB. Thermogravimetric analysis of coal char combustion kinetics. J Iron Steel Res Int. 2014;21:897-904. 
32. Zeng $X$, Wang F, Wang YG, Li AM, Yu J, Xu GW. Characterization of char gasification in a micro fluidized bed reaction analyzer. Energ Fuel. 2014;28: 1838-45.

33. Jayaraman K, Kok MV, Gokalp I. Pyrolysis, combustion and gasification studies of different sized coal particles using TGA-MS. Appl Therm Eng. 2017;125:1446-55.

34. Cai JQ, Wang YP, Zhou LM, Huang QW. Thermogravimetric analysis and kinetics of coal/plastic blends during co-pyrolysis in nitrogen atmosphere. Fuel Process Technol. 2008;89:21-7.

35. Branca C, Di Blasi C. Global kinetics of wood char devolatilization and combustion. Energ Fuel. 2003;17:1609-15.

36. Bungay VC. Kinetic study on the pyrolysis and gasification of plastic waste. Chem Eng Trans. 2017;56:193-8.

37. Ozsin G, Putun AE. Kinetics and evolved gas analysis for pyrolysis of food processing wastes using TGA/MS/FT-IR. Waste Manage. 2017;64:315-26.

38. Brittain $H G$, Bruce RD. Thermal analysis. In: Ahuja $\mathrm{S}$, Jespersen $\mathrm{N}$, editors. Comprehensive analytical chemistry. Amsterdam: Elsevier; 2006. p. 63-109.

39. Chen W, Annamalai K, Sun JF, Chen YM. Chemical kinetics of bean straw biofuel pyrolysis using maximum volatile release method. Korean J Chem Eng. 2016;33:2330-6.

40. Zhou LM, Zhang GJ, Reinmoller M, Meyer B. Effect of inherent mineral matter on the co-pyrolysis of highly reactive brown coal and wheat straw. Fuel. 2019;239:1194-203.

41. Zhang XS, Lei HW, Zhu L, Zhu XL, Qian M, Yadavalli G, et al. Thermal behavior and kinetic study for catalytic co-pyrolysis of biomass with plastics. Bioresour Technol. 2016;220:233-8.

42. Wu ZQ, Li YW, Zhang B, Yang WC, Yang BL. Co-pyrolysis behavior of microalgae biomass and low-rank coal: kinetic analysis of the main volatile products. Bioresour Technol. 2019;271:202-9.

43. Eskander SB, Tawfik ME, Tawfic ML. Mechanical, flammability and thermal degradation characteristics of rice straw fiber-recycled polystyrene foam hard wood composites incorporating fire retardants. J Therm Anal Calorim. 2018;132:1115-24

44. Striugas N, Skvorcinskiene R, Paulauskas R, Zakarauskas K, Vorotinskiene L. Evaluation of straw with absorbed glycerol thermal degradation during pyrolysis and combustion by TG-FTIR and TG-GC/MS. Fuel. 2017;204:227-35.

45. Fang SW, Yu ZS, Lin Y, Lin YS, Fan YL, Liao YF, et al. A study on experimental characteristic of co-pyrolysis of municipal solid waste and paper mill sludge with additives. Appl Therm Eng. 2017;111:292-300.

46. Ma ZQ, Chen DY, Gu J, Bao BF, Zhang QS. Determination of pyrolysis characteristics and kinetics of palm kernel shell using TGA-FTIR and modelfree integral methods. Energ Convers Manage. 2015;89:251-9.

47. Blazquez G, Perez A, lanez-Rodriguez I, Martinez-Garcia C, Calero M. Study of the kinetic parameters of thermal and oxidative degradation of various residual materials. Biomass Bioenerg. 2019;124:13-24.

48. Parshetti GK, Quek A, Betha R, Balasubramanian R. TGA-FTIR investigation of co-combustion characteristics of blends of hydrothermally carbonized oil palm biomass (EFB) and coal. Fuel Process Technol. 2014;118:228-34.

49. Stephen JL, Periyasamy B. Innovative developments in biofuels production from organic waste materials: a review. Fuel. 2018;214:623-33.

50. Lignell A, Khriachtchev L, Pettersson M, Rasanen M. Large blueshift of the H$\mathrm{Kr}$ stretching frequency of $\mathrm{HKrCl}$ upon complexation with $\mathrm{N}_{2}$. J Chem Phys. 2002;117:961-4

51. Jiang LB, Yuan XZ, Li H, Chen XH, Xiao ZH, Liang J, et al. Co-pelletization of sewage sludge and biomass: thermogravimetric analysis and ash deposits. Fuel Process Technol. 2016;145:109-15.

52. Sigot $L$, Ducom $G$, Germain P. Adsorption of hydrogen sulfide $\left(\mathrm{H}_{2} \mathrm{~S}\right)$ on zeolite (Z): retention mechanism. Chem Eng J. 2016;287:47-53.

\section{Publisher's Note}

Springer Nature remains neutral with regard to jurisdictional claims in published maps and institutional affiliations.

Ready to submit your research? Choose BMC and benefit from:

- fast, convenient online submission

- thorough peer review by experienced researchers in your field

- rapid publication on acceptance

- support for research data, including large and complex data types

- gold Open Access which fosters wider collaboration and increased citations

- maximum visibility for your research: over $100 \mathrm{M}$ website views per year

At BMC, research is always in progress.

Learn more biomedcentral.com/submissions 